\title{
Parental Influence and Undergraduates' Career Choice Intentions
}

\author{
Tan Fee Yean ${ }^{a^{*}}$, Tay Lee Chin \\ aSchool of Business Management, University Utara Malaysia, 06010 UUM Sintok, Kedah, Malaysia \\ ${ }^{b}$ Graduate School of Business, SEGi University, 47810 Selangor, Malaysia \\ *Corresponding author: feeyean@uum.edu.my
}

Article history: Received 25 February 2019 Received in revised form: 05 April 2019 Accepted: 28 May 2019 Published online: 29 August 2019

\begin{abstract}
The underrepresentation of graduates in science, technology, engineering and mathematics (STEM) fields has become a matter of grave concerns for many governments around the world, especially Malaysia, as STEM education is the key to economic progress. The aim of this study is to identify the effects of parental influence on undergraduate students' career choices. For the purpose of this study, data were obtained with the use of structured questionnaires which were administered to 242 final year undergraduate students within STEM disciplines. The regression analysis revealed that continuous information and support from parents have a lasting positive impact on students' interest in STEM careers. Results from this research can be useful for education policymakers and carry valuable information for further research in education and career planning.
\end{abstract}

Keywords: STEM careers; career choice; intention; parental influence.

Abstrak

Bilangan siswazah yang terlibat dalam kerjaya berasaskan sains, teknologi, kejuruteraan dan matematik (STEM) yang kian merosot telah menimbulkan kebimbangan di seluruh dunia, khususnya Malaysia kerana pendidikan STEM adalah kunci kepada masa depan ekonomi. Tujuan kajian ini adalah untuk mengenal pasti kesan pengaruh ibu bapa terhadap pilihan kerjaya siswazah. Untuk tujuan kajian ini, data telah dikumpulkan dengan menggunakan soal selidik berstruktur. Seramai 242 orang pelajar tahun akhir yang mengikuti pengajian STEM telah menyertai kajian ini. Analisis regresi menunjukkan bahawa maklumat berterusan dan sokongan daripada ibu bapa mempunyai impak positif dan mempengaruhi minat pelajar terhadap kerjaya STEM. Keputusan daripada kajian ini boleh digunakan oleh perancang dasar untuk tujuan perancangan dan pemutusan dasar pendidikan. Selain itu, keputusan kajian turut menyumbang informasi berguna bagi memperkasa kajian pendidikan dan perancangan kerjaya.

Kata kunci: STEM kerjaya; pilihan kerjaya; niat; pengaruh ibu bapa.

(C) 2019 Penerbit UTM Press. All rights reserved

\subsection{INTRODUCTION}

Technology is continuously expanding, and thus, Science, Technology, Engineering and Mathematics (STEM) education is important in all facets of our lives. For instance, weather can be predicted by technology and new systems are constantly developed to produce even more precise forecasts; such a forecasting system can help us plan days, weeks or even years in advance. Technology has also transformed the education landscape; educational mobile apps (i.e. Science and Technology invention) including E-Books, E-library, educational videos provide easy access to quality educational materials, enhancing the experience of learning and teaching thus improving the lives of educationists and students. In addition, most of the top paying jobs are in STEM-related fields (e.g., engineers, information technology professionals and other technical professionals); as cited by Lim (2018), STEM employees can earn up to RM18,000 per month based on the 2017 Salary Report by JobStreet.com. Amidst the fast-growing STEM industries and a relatively rapid growth in employment and wages in STEM-related fields, there is a declining interest in STEM occupation choices among the Malaysian undergraduates. The National Science and Technology Enrolment Policy ratio target of 60:40 which guaranteed more STEM programs enrollment at tertiary level has not been achieved, leading to a worrying shortfall of workers possessing the skills used in STEM (Aina \& Zafira, 2016). The inability to supply skilled STEM workers to meet the needs of new technological era will result in an acute shortage of STEM workforce. Malaysia's science and technology sector is projected to yield nearly one million jobs openings by 2020 (Aina \& Zafira, 2016). If these vacancies remain unfilled, Malaysia need to be prepared to face the challenge of a serious STEM skill and talent shortage (e.g. architects, engineers and science related professionals), and thus fail to achieve an innovation-centric economy with a balanced development of socioeconomic dimensions, and become the world's top 20 nations (Rozana, 2018). Hence, this study aims to investigate STEM career choice intentions of undergraduates.

Parents play a crucial role in all aspects of the lives of their children including career selection (Wong \& Liu, 2010; Liu, McMahon \& Watson, 2015; Michele \& Francesco, 2018; Guan, Wang, Gong, Cai, Xu, Xiang, Wang, Chen, Hu \& Tian, 2018). Children 
(undergraduates) tends to favor ideal careers like that of their parents over others if their careers provide satisfaction, accomplishments, prestige, social status and comfortable lifestyle (Zhou, Sun, Guan, Li \& Pan, 2013; Zhou, Guan, Xin, Mak \& Deng, 2016). On the other hand, if parents complain about their careers, their children (undergraduates) are more likely to choose other careers (Zhou et al., 2013; Zhou et al., 2016). Nevertheless, there is a scarcity of research on how parental influences are associated with undergraduates' career choice (Perry, 1996; 1997; Stritch \& Christensen, 2016). A large body of literatures has examined work-integrated learning (McIlveen, Brooks, Lichtenberg, Smith, Torjul, Tyler, 2011; Jackson, 2015), and the contribution of personality factors such as the need for achievement, self-efficacy (Hult, Burke-Smalley, Jones, 2017; Dalton, Buchheit \& McMillan, 2014), and career attitudes to career choice intentions (Sargent \& Domberger, 2008; Abessolo, Hirschi \& Rossier, 2017). However, the extent to which parental influence relates to career choice intention (STEM career) still remains unclear. With this in mind, the purpose of this study is to examine the effects of parental influence on students' STEM career choice intention. As such, this study adds to the growing body of literatures on the roles of parents in shaping their children's career choices. In the following section, this paper first review the definition of STEM careers, STEM career choice and the relationships between parental influence and career choice intention. Section three presents research methodology while section four reports data analysis and findings. Section five shows the conclusion.

\subsection{LITERATURE REVIEW}

\section{STEM Career Choice Intention}

STEM careers can be defined as jobs where STEM workers use their knowledge of science, technology, engineering and mathematics to understand how the world works and to solve problems (Vilorio, 2014). STEM careers namely computer network architects, animal scientists, biomedical engineers and web developers often involve the use of computers and other tools (Vilorio, 2014). STEM careers are often related to each other. For instance, mathematics provides the foundation for physics, while physics in turn is usable in medicine.

STEM career choice intention can be defined as an individual's inclination and preference to choose a career in STEM fields (Broadbridge \& Parsons, 2005), giving priority to one occupation (e.g., STEM) over another (Ozbilgin, Kusku, Erdogmus, 2005). In a similar vein, Gokuladas (2010) posited that STEM career choice intention is the self-assessment of one's capabilities and competencies and the evaluation of other career options to effectively match one's needs to the preferred career choice (i.e. STEM).

\section{Parental Influence and STEM Career Intention}

Previous studies (Constantine, Wallace, \& Kindaichi, 2005; Stambler, 1998; Turner \& Lapan, 2002; Whiston \& Keller, 2004) showed that parental influence is related to STEM career choice intention. Parents' advice and guidance exert the influence on their children's career choice intention as parents have regular interactions with their children compared to teachers and career counselors (Clutter, 2010). Parents often begin the career discussions with their children as early as possible, since their childhood. Children should feel comfortable talking to their parents about anything, including their own aspirations for the future. By having an open relationship with parents, children can be exposed to various career options that might be a good fit to their interests and competencies (Cheng, Tsai \& Kao, 2016). Parents may introduce their children to friends, business colleagues or other associates who have similar career path that their children wants to explore. Parents may also encourage their children to gather as much information as possible related to their interests. Choosing a career based on their preferences or parents' favoritisms allows children to discover great career possibilities (Chan, 2013).

In addition, parents can influence their children's career choice intentions by exposing them to desired careers (Vargas-Benitez, 2017). This is because high parental aspirations such as strong parent-child relationships, open communications, and parents' trust and support, allow the opportunity to experience career exploration activities, future planning and career choice intentions (Okamopelola, 2014). Parents can influence their children's career choices both intentionally and inadvertently. By the time children move into adolescence, they begin seriously considering their futures, often looking to their parents either as role models or for career advice. As such, parents can serve as the career role model for their children (Eccles \& Davis, 2005; Garg, Melanson \& Levin, 2006; Kniveton, 2004; Wright \& Perrone, 2008), mainly because their regular presence and interactions with their children (Bloom, 2018). In addition, the success of their parents' careers, made the children want to follow in their parents' footsteps. For example, a father who is a prominent animal scientist in society, his children may consider a path to become an animal scientist too. Conversely, if the children found that their father, a marine engineer, often had to sacrifice family time, giving his career more importance to fulfill family needs, the children may not choose marine engineer as their future career.

Besides that, parental beliefs, values and expectations toward STEM fields are key factors to why their children (undergraduates) choose to engage in STEM professions (Eccles, 1993; Okamopelola, 2014). Children are likely to be more interested in pursuing STEMrelated occupations with strong parental involvement, such as regular emphasis on STEM careers. For instance, children, influenced by their parenting beliefs, values and expectations, implicitly or explicitly, for the past 20 years are likely to be more interested in STEM careers and have favorable impression toward the STEM fields (Singaravelu, White \& Bringaze, 2005). For instance, an adolescent whose parents constantly emphasis on the importance of masculine attributes such as independent, analytical, and assertive which are perceived to be valuable, will pursue a career in STEM fields. Therefore, it is logical to predict the effects of parental influences on university students' career choice intentions, particularly toward STEM-related careers.

\subsection{METHODOLOGY}

\section{Sample and Procedure}

The sample of this research comprised of final year undergraduates within STEM disciplines in a Malaysian public university in the Northern region of Peninsular Malaysia. A technique of purposive sampling was used. Out of 250 questionnaires distributed, 242 
questionnaires were usable for analysis. The frequency analysis showed that majority of the respondents were female (54.1\%). 87 respondents were engineering students, 81 enrolled in technology courses, and 74 respondents were in medical courses.

\section{Measurements}

Parental influence was measured using a 6-item scale adapted from Wong and Liu (2010). An example of the items is "I consider my parents' opinion when selecting my career choice". Meanwhile, STEM career choice intention was measured by a 13-item adapted from Tyler-Wood, Knezek and Christensen (2010) - Career Interest Questionnaire (CIQ). Sample item is "I will get a job in a science-related area". A 5-point Likert-scale that ranged from (1) stronger disagree to (5) stronger agree was used as the response scale.

\subsection{RESULTS AND DISCUSSION}

Internal consistency reliabilities (Cronbach's Alpha) of the independent and dependent variables (i.e., parental influence and STEM career choice intention) of this study were assessed and the results found that both variables has satisfactory reliability values (i.e., parental influence $=0.921$ and STEM career choice intention $=0.736)$ that is above the threshold value of 0.60 as suggested by Ho $(2014)$.

Besides that, in order to examine the effect of parental influence on STEM career choice intention among undergraduates, a linear regression analysis was performed via Statistical Package for the Social Sciences (SPSS) version 22.0. Before performing regression analysis, few assumptions such as normality, linearity, homoscedasticity, independence of residuals and the absence of multicollinearity have been tested and met as indicated by Ho (2014). Table 1 depicts the results of regression analysis conducted.

The results of regression analysis revealed significant positive relationship between parental influence and STEM career choice intention $(\beta=0.286, \mathrm{p}<0.01)$. These results signified that the final year undergraduate's students within the STEM disciplines are likely to engage in STEM careers if their parents want them working in STEM industries. Parents (i.e. those parents that engaged in STEM industries) might want their children to follow their footsteps, and thus are likely to encourage their children to engage in the similar careers as them. Parents have the ability to inspire their children as they are the people who are close to them. Parents are role models or source of support for their children to pursue in particular STEM industries. Similar to the finding, undergraduates are likely to ask their parents' opinion before making career decisions. Parents serve as an influencer to undergraduates' STEM career choice intentions.

Table 1 Regression results of parental influence on STEM career choice intention

\begin{tabular}{lccccc}
\hline & \multicolumn{2}{c}{ Unstandardized Coefficients } & $\begin{array}{c}\text { Standardized } \\
\text { Coefficients }\end{array}$ & $\boldsymbol{t}$ & Sig. \\
\cline { 2 - 6 }$($ Constant $)$ & $\boldsymbol{\beta}$ & Std. Error & & 17.655 & 0.000 \\
\hline Parental influence & 2.883 & 0.163 & $0.286^{* *}$ & 4.616 & 0.000 \\
\hline
\end{tabular}

Note: **p $<0.01$; Dependent variable $=$ STEM career choice intention; Correlation coefficient $\mathrm{R}=0.286^{* *} ; \mathrm{R}^{2}=0.08$

\subsection{CONCLUSION}

The findings of this study showed that parental influence is significantly related to STEM career choice intention. This finding is consistent with O'Brien (1996), Rainey and Borders (1997), Vilanova and Puig (2016), Rutledge and Madi (2017), Guan et al. (2018) who found that parental influences are the key that exert a notable effect on their children's career choice intention. Based on the findings, the study developed several recommendation for STEM industries. To nurture interest in STEM, the industry can encourage parents and students to obtain accurate STEM industry information from reliable sources and shares the information with their children, or peers and friends. This leads to parental encouragement, deemed crucial to implement the efforts aimed at encouraging their children to consider pathways into STEM careers. In this regard, it is suggested that STEM industries should provide more career talks to both parents and students and offer more field trips and internships opportunities for students to experience STEM-related jobs.

Given parents' great influence over graduates' intention to choose STEM careers, generous benefits package is important to attract and retain top STEM talents. As such, STEM industries should develop competitive salary packages and more flexible benefits. On the other hand, this study is not without limitations. This study is cross-sectional designed which does not prove causality. Future research should take the longitudinal approach to track changes in these relationships. For instance, the relationship between parental influence and STEM career choice intention gradually attenuates over time. Moreover, future research can examine other variables such as career interests, career goals and peer influences on STEM career choice intention (Raque-Bogdan, Klingaman, Martin \& Lucas, 2013). Finally, this study was conducted among undergraduates of STEM courses and it is suggested that further research can be conducted among the undergraduates from different level of studies such as STEM diploma and advanced diploma.

\section{References}

Aina, N., \& Zafira, A. (2016, May 23). Too few STEM students. Retrieved from https://www.nst.com.my/news/2016/05/147260/too-few-stem-students Abessolo, M., Hirschi, A., \& Rossier, J. (2017). Work Values Underlying Protean And Boundaryless Career Orientations. Career Development International, 22(3), 241-259

Bloom, S. (2018). The Importance Of Parents As Role Models. Retrieved from https://www.livestrong.com/article/110276-importance-parents-role-models/ 
Broadbridge, A., \& Parsons, E. (2005). Gender and Career Choice: Experiences Of UK Charity Retailer Managers. Career Development International, 10(2), 80-97 Chan, C. C. (2013). The Relationship Among Social Support, Career Beliefs, Career Self-Efficacy, And Career Development Of College Athletes (Unpublished doctoral dissertation). Taipei,Taiwan: National Taiwan Normal University.

Cheng, C. F., Tsai, H. H., \& Kao, C. C. (2016). The Construction Of A Career Developmental Counseling Model For Taiwanese Athletes. Physical Education Journal, 49(4), 443-464.

Constantine, M. G., Wallace, B. C., \& Kindaichi, M. M. (2005). Examining Contextual Factors In The Career Decision Status Of African American Adolescents. Journal of Career Assessment, 13, 307-319.

Clutter, C. (2010). The Effect Of Parental Influence On Their Children's Career Choice. Kansas State University

Dalton, D. W., Buchheit, S., \& McMillan, J. J. (2014). Audit and Tax Career Paths In Public Accounting: An Analysis Of Student And Professional Perceptions. Accounting Horizons, 28(2), 213231.

Eccles, J.S. (1993). School and Family Effects On The Ontogeny Of Children's Interests, Self-Perceptions, And Activity Choice", in Jacobs, J. (Ed.), Nebraska Symposium on Motivation: 40. Developmental Perspectives on Motivation, University of Nebraska Press, Lincoln, NE, pp. 145-208.

Eccles, J., \& Davis, P. E. (2005). Influences of Parents' Education On Their Children's Educational Attainments: The Role Of Parent And Child Perceptions. London Review of Education, $191-204$.

Garg, R., Melanson, S., \& Levin, E. (2006). Educational Aspirations Of Male And Female Adolescents From Single-Parent And Two Biological Parent Families: A Comparison Of Influential Factors. Journal of Youth Adolescence, 1010 - 1023.

Gokuladas, V. (2010). Technical and Non-Technical Education And The Employability Of Engineering Graduates: An Indian Case Study. International Journal of Training and Development, 14(2), 130-143.

Guan, Y., Wang, Z., Gong, Q., Cai, Z., Xu, S. L., Xiang, Q., Wang, Y., Chen, S. X., Hu, H., \& Tian, L. (2018). Parents' Career Values, Adaptability, Career-Specific Parenting Behaviors And Undergraduate Career Adaptability. The Counseling Psychologist, 46(7), 922-946

Ho, R., 2014. Handbook of Univariate And Multivariate Data Analysis with IBM SPSS. Boca Raton, US: CRC Press.

Hult, T., Burke-Smalley, L. A., Jones, C. (2017). An Empirical Investigation Of Student Career Interests In Auditing Using The Big Five Model Of Personality. Advances in Accounting Education: Teaching and Curriculum Innovations, 20, 1-31

Kniveton, B. (2004). The influences and Motivations On Which Students Base Their Choice Of Career. Research in Education, 72(1), 47-59

Jackson, D. (2015). Career Choice Status Among Undergraduates And The Influence Of Work-Integrated Learning. Australian Journal of Career Development, 24(1), 3-14

Lim, S. M. (2018, July 21). STEM Jobs In High Demand. Retrieved from http://www.focusmalaysia.my/Income/stem-jobs-in-high-demand

Liu, J., McMahon, M., \& Watson, M. (2015). Parental Influence On Child Career Development In Mainland China: A Qualitative Study. The Career Development Quarterly, 63(1), 74-87

Mcllveen, P., Brooks, S., Lichtenberg, A., Smith, M., Torjul, P., \& Tyler, J. (2011). Perceptions of Career Development Learning And Work-Integrated Learning In Australian Higher Education. Australian Journal of Career Development, 20(1), 32-41.

Michele, R., \& Francesco, V. (2018). From the Cradle To The Grave: The Influence Of Family Background On The Career Path Of Italian Men. Oxford Bulletin of Economics, 80(6), 1-27

O'Brien, K. M. (1996). The Influence Of Psychological Separation And Parental Attachment On The Career Development Of Adolescent Women. Journal of Vocational Behavior, 48, 257-274.

Okamopelola, I. (2014). Effects of Parental Influence On Adolescents Career Choice. Journal of Research and Method in Education, 4(3), 44-57

Ozbilgin, M., Kusku, F., Erdogmus, N. (2005). Explaining influence on career choice: The case of MBA students in comparative perspectives. The International Journal of Human Resource Management, 16(1), 2000-2028

Perry, J. L. (1996). Measuring Public Service Motivation: An Assessment Of Construct Reliability And Validity. Journal of Public Administration Research and Theory, 6(1), 5-22.

Perry, J.L. (1997). Antecedents Of Public Service Motivation. Journal of Public Administration Research and Theory, 7(2), 181-197.

Rainey, L. M., \& Borders, D. L. (1997). Influential Factors In Career Orientation And Career Aspiration Of Early Adolescent Girls. Journal of Counseling Psychology, 44, 160-172.

Raque-Bogdan, T. L., Klingaman, E. A., Martin, H. M., \& Lucas, M. S. (2013). Career-Related Parent Support and Career Barriers: An Investigation of Contextual Variables. The Career Development Quarterly, 61,339-353.

Rozana, S. (2018, July 24). Varsities Nurture Love Of STEM In Schools. Retrieved from https://www.nst.com.my/education/2018/03/342360/varsities-nurture-lovestem-schools

Rutledge, E., \& Madi, M. (2017). Parental Influence On Female Vocational Intentions in the Arabian Gulf. International Journal of Manpower, 38(2), 145-159

Sargent, L.D., \& Domberger, S.R. (2007). Exploring the Development Of A Protean Career Orientation: Values And Image Violations. Career Development International, 12(6), 545-564.

Singaravelu, H., White, L., \& Bringaze, T. (2005). Factors Influencing International Students' Career Choice. Journal of Career Development, 46-59.

Stambler, B.J. (1998). An Examination Of The Effects Of Parental Influence On Secondary School Completion. Unpublished PhD dissertation, State University of New York at Albany, Albany, NY.

Stritch, J. M., \& Christensen, R. K. (2016). Raising the Next Generation Of Public Servants? Parental Influence On Volunteering Behavior And Public Service Career Aspirations. International Journal of Manpower, 37(5), 840-858

Tyler-Wood, T., Knezek, G., \& Christensen, R. (2010). Instruments for assessing interest in STEM content and careers. Journal of Technology and Teacher Education, 18(2), 341-363.

Turner, S., \& Lapan, R. T. (2002). Career Self-Efficacy And Perceptions Of Parent Support In Adolescent Career Development. The Career Development Quarterly $51,44-55$.

Whiston, S.C., \& Keller, B.K. (2004). The Influences Of The Family Of Origin On Career Development: A Review And Analysis. The Counseling Psychologist, 32(4), 493-568

Wong, S. C. K., \& Liu, G. J. (2010). Will Parental Influences Affect Career Choice? Evidence From Hospitality And Tourism Management Students in China. International Journal of Contemporary Hospitality Management, 22(1), 82-102.

Wright, S. L., Perrone, K. M. (2008). The Impact of Attachment on Career-Related Variables: A Review of the Literature and Proposed Theoretical Framework to Guide Future Research. Journal of Career Development, 35, 87-106.

Vargas-Benitez, J. (2017, June 23). Parental Influence On The Career Choice And Decision Making Of Adolescents. Retrieved from https://www.livestrong.com/article/1007066-parental-influences-career-choices-decisionmaking-adolescents/ on 23 July 2018

Vilanova, A., \& Puig, N. (2016). Personal Strategies For Managing A Second Career: The experiences of Spanish Olympians. International Review for the Sociology of Sport, 51(5), 529-546.

Volorio, D. (2014, January 15). STEM: Intro to Tomorrow's Jobs. Retrieved from https://www.bls.gov/careeroutlook/2014/spring/art01.pdf on 23 July 2018

Zhou, W., Guan, Y., Xin, L., Mak, M. C. K., \& Deng, Y. (2016). Career Success Criteria And Locus Of Control As Indicators Of Adaptive Readiness In The Career Adaptation Model. Journal of Vocational Behavior, 94, 124-130

Zhou, W., Sun, J., Guan, Y., Li, Y., \& Pan, J. (2013). Criteria of Career Success Among Chinese Employees: Developing A Multidimensional Scale With Qualitative And Quantitative Approaches. Journal of Career Assessment, 21, 265-277. 